\title{
Philosophy as Political Technē: \\ The Tradition of Invention in Simondon's Political Thought
}

Dr Andrea Bardin

\begin{abstract}
Gilbert Simondon has recently attracted the interest of political philosophers and theorists, despite he is rather renowned as a philosopher of technics - as the author of Of the Mode of Existence of Technical Objects - who also elaborated a general theory of complex systems in Individuation in the Light of the Notions of Form and Information. A group of scholars has developed Gilles Deleuze's early suggestion that Simondon's social ontology might offer the basis for a re-theorisation of radical democracy. Others, following Herbert Marcuse, have instead focused on Simondon's analysis of the relationship between technology and society. However, only a joint study of Simondon's two major works can reveal their implicit political stakes. As I will argue, Simondon's anti-Aristotelianism and his anti-Heideggerian understanding of the Greek origins of philosophy, allow us to conceive philosophical thought as a 'tradition of invention', that is, a pedagogical techne endowed with the political task of maintaining the openness of the social system and allowing normative invention to emerge from within.
\end{abstract}

\section{KEYWORDS}

Simondon, Canguilhem, Heidegger, Aristotle, Pedagogy and Politics, Technē and Philosophy

In recent years, the French philosopher Gilbert Simondon has been feted as an original political thinker. In many ways, the very absence of an explicit political position in his writings helps to explain the lively debate surrounding the political questions that appear to emerge from both his philosophy of individuation and his philosophy of technics, which he developed respectively in Individuation in the Light of the Notions of Form and Information, and Of the Mode of Existence of Technical Objects, first presented for his doctorate in 1958.

A group of scholars has, on this score, sought to renew Gilles Deleuze's early suggestion that Individuation might offer the basis for a social ontology of the "transindividual collective" (Deleuze, 1966, p. 124) capable of contrasting the methodological individualism dominating much contemporary political thinking (Balibar, 1997, pp. 10-11, 22-23; Toscano 2006, pp. 136-42, 147-51; Del Lucchese, 2009; Combes, 2013, pp. 25-50). Other scholars have instead followed up on Herbert Marcuse's cursory reading (1964, p. 159) of Simondon's analysis of the relationship between technology and society originally outlined in Du mode (Feenberg, 1991, pp. 194-95; Stiegler, 1998, pp. 80-94; see also De Boever, 2012). However, as the following pages will seek to demonstrate, only a joint study of the two texts can reveal their 
implicit political stakes and clarify the genuinely political significance of Simondon's thought.

This article examines the complex combination of epistemology, psycho-sociology, and philosophy of technology that makes up Simondon's æuvre (see Barthélémy, 2008; Guchet, 2010; Bardin, 2015), and attempts to articulate what contribution his work can represent to the understanding of the political nature of philosophy itself. It will start by showing how Simondon's model for understanding systems in general, and social systems in particular, represents an alternative to the traditional organic and mechanical models of the body politic. What links Simondon's twofold research into one project is an anti-teleological understanding both of the functioning of technical objects, and of psychic and collective individuation, with the latter grounding his theory of social systems. This theory is founded on a concept of culture as the regulatory apparatus of social systems. For Simondon, culture mediates between the normative innovation triggered by the emergence of what he calls 'technicity', namely, the theoretical and behavioural norms implicit in technical activity and technical objects, and the continuity granted by the social reproduction of the symbolic order. However, according to Simondon, the symbolic objects produced by philosophy - which is a subset of culture - enjoy a peculiar relation to the destabilising and inventive force of technicity that remains to be explored.

With this background in place, the article goes on to demonstrate that Aristotle's and any other subordinations of techne to what is considered an eminent human activity, either contemplation (theoresis) or action (praxis), is grounded on the same ontological subordination and de-politicisation of production (poiesis). Simondon's attack on Aristotle's hylomorphism suggests that philosophy should instead be conceived as political techne, whose products are inherently related to technical mentality and pedagogy. Such a conception is what separates Simondon from Heidegger. As an analysis of Simondon's interpretation of pre-Socratic thought will demonstrate, his care for technicity aims at reversing the Heideggerian 'care' [Sorge] of thinking against its alleged reduction to technics. According to Simondon, 'technicity' marks the very origin of philosophical thought. Since its very inception with the Ionian thinkers, philosophy has been related to technical problems the 
solution of which have an impact on social relations and norms (Individuation, pp. 511-16). In this sense technicity is far from politically neutral, and philosophy can be seen as an intrinsically political activity whose effects have always been to spark normative innovation and to enable its integration into culture.

I will argue that Simondon's unconventional, and clearly anti-Heideggerian, understanding of pre-Socratic thought allows him to view philosophy as a 'tradition of invention', that is, as a pedagogical techne entrusted with the political task of maintaining the openness of society and allowing normative invention to emerge from within. This perspective will support my hypothesis that although the ontological and epistemological issues raised in Individuation go far beyond the philosophy of technics developed in Du mode, the two works should be read together against the background of Simondon's overall endeavour to address the contrast between culture and technology. Indeed, this project was political qua pedagogical, and Simondon's two major philosophical works were intended by their author as symbolic artefacts that aimed to integrate technical normativity into culture so as to trigger political transformations.

\section{What Model for the Body Politic?}

Following the scientific revolution, the clockwork nature theorised by early modern natural philosophers began to colonise all fields of the philosophical imaginary. In political theory, although the traditional organic model - the origin of which was both biological and theological (Kantorowicz, 1957) - maintained an undisputed scientific primacy, the idea of a 'political automaton' also had an enormous impact. The metaphor of the machine advanced from the nature-machine to the animal-machine and, finally, to the theory of the state, leading, from Hobbes to Frederick the Great, to a new understanding of the body politic comprehended from the perspective of its modern, technological administration (Mayr, 1986, pp. 102-14; Harvey, 2007, pp. 35-38). In opposition to this theoretical course, the metaphor was intended to serve as a warning against any attempt to restrict the liberty of human beings and their capacity for self-regulation to the supposedly automatic, 'inhuman', functioning of nature and the state (Mayr, 1986, pp. 139-89). The mechanistic imaginary forged in early 
modern philosophy therefore nurtured different forms of metaphysical commitment either for or against the mechanisation of human beings and society, and thus also prescribed a choice between a closed community characterised by a strong natural identity or an artificial society of atomic individuals. This apparent alternative still dominated the Positivist attempt to provide society with a regulatory apparatus that synthesised the advantages of organicism and those of mechanism (Schlanger, 1995, pp. 57-60).

Simondon's theory of social systems proceeds from a point beyond this duality, following Georges Canguilhem's refutation of the Positivist synthesis. Although Canguilhem states that society is 'both machine and life' (Canguilhem, 2002, p. 121), he argues that it does not possess a regulatory apparatus, since 'justice, the supreme regulation, does not appear in the form of an apparatus produced by society itself' (Canguilhem, 2002, p. 122). In this context, Canguilhem defines 'justice' as an act of political invention that must be distinguished from the 'institutions of justice'. He explains that it can only come 'from elsewhere [d'ailleurs]', as is 'added onto [surajoutée]' society, originating outside of any homeostatic or reproductive process (Canguilhem, 2002, p. 121-25). Setting himself against the ancient myth of an organic body politic - in which justice resides in its first principle, whether transcendent (divine) or immanent (natural) - and also against the modern mechanistic conception of a social automaton - in which justice depends on a rationally established normativity - Canguilhem follows Bergson (1932) in seeing society as characterised by a general tendency towards entropy that is punctuated by exceptional moments of heroic invention. Irrespective of whether this Bergsonian vitalism is Canguilhem's (or even Bergson's) final word on the subject, it should be understood as the basis of Simondon's attack on the false alternative between biological and mechanical models, and his conceptualisation of politics as a field that has no fixed teleology and is open to normative invention.

Simondon's understanding of social regulation functions as a critique of both the ancient notion of a natural or divine justice that is inherent to the body politic, and the modern myth of an artificial body politic, which he sees as still constituting Norbert Wiener's technocratic cybernetics (1954). ${ }^{2}$ From Simondon's perspective, both these approaches 
ultimately disavow the social system's structural lack of regulation through the belief in an underlying teleology. In the first case, conceptions of divinely established or natural goals inherent to the body politic ground attempts to maintain and defend its overall functioning as defined by these goals. In the second, conceptions of a purely mechanical body politic serve to legitimate the model of a disembodied rationality seeking technological control over the variability of nature in general, and of human nature in particular.

For Simondon, Wiener's cybernetic model represents the latest incarnation of the deterministic and homeostatic machine that originated in seventeenth-century mechanical philosophy. The limitations of this model can be delineated through Wiener's own concept of metastability (Simondon, 2014, p. 236). Any 'stable' system is doomed to collapse, as it is unable to convert internal tensions through structural reconfigurations, and is thus subject to an inevitable entropic tendency (Individuation, pp. 206, 213). 'Metastability', on the other hand, characterises systems whose structure is open to further transformation because its equilibrium contains potential energy that is not fully stabilised. This concept allows Simondon to define society as a non-homeostatic system:

Nothing allows us to consider society as the domain of an absolute homeostasis. Norbert Wiener seems to put forward an unnecessary assumption [postulat de valeurs], namely, that proper homeostatic regulation is an ultimate end of societies and the ideal that should drive every act of government. (Du mode, p. 151) Beyond the alternative between a naturally stable, organic body politic and an artificially stabilised, mechanical social automaton, Simondon is instead drawn to the model of an 'open machine', comprising the metastability of the system and the indeterminacy of the processes to which it is always irreducibly exposed. According to him, the regulatory apparatus of social systems cannot be tied to any specific form of finality, whether an internal and reproductive finality, as in an organism, or an externally imposed and deterministic one, as in a machine. Both types of model are too abstract and hence incapable of describing the functioning of social systems accurately. In fact, they both fall short of capturing the actual functioning of real organisms and machines. Indeed, there can be no such thing as an automaton: any actual machine, such as an organism, 'presupposes a regulation' precisely 
because it 'harbours a certain degree of indeterminacy in its functioning' that allows for information exchange with the environment (Du mode, p. 138).

From this perspective, the two classical models for the body politic can be seen to lead to the same reduction of political invention to the normal functioning of the system, that is, to either a natural (internal) finality, or a mechanical (external) one. To these models Simondon instead adds a decisive 'quantistic' dimension (Barthélémy, 2008, pp. 24-34). At all levels - physical, biological, psychic, and collective - systems can only survive so long as they possess a sufficient margin of indeterminacy that allows them to undergo change. This evolutionary openness, of course, entails a degree of risk, but without it the survival of the system as a whole would be impossible. Intervention aimed at interrupting the automatic inertia of the system is necessary in order to contrast its entropic tendencies.

In his theory of social systems, Simondon defines such a risky, though necessary, intervention as an 'act of government'. Such a political act of invention is less a kind of revolutionary event, and more an evolutionary risk that must be taken. By breaking the instituted order, such a gesture is always dangerous, and yet it is required to stop the order from steadily dissolving. As long as a situation is rich in potentials (i.e. metastable), an act of government remains possible:

Just as the living relies on homeostases for developing and becoming instead of remaining perpetually in the same state, in the act of government there is also a force of absolute origination [force d'avènement absolu], which, although relying on homeostases, uses and exceeds them. (Du mode, p. 151)

By 'act of government' Simondon here does not mean an act aimed at the reproduction of existing conditions depending on human nature, but rather a form of artisanal techne of invention that seeks to establish new interactions between existing processes. Such a technopolitical gesture is a combination of theory and practice. In this sense, a theory of the social system makes possible the establishment of the conditions of emergence of an act of government, while a practical decision entails an acknowledgement of the impossibility of planning its outcomes entirely. Simondon thus conceives of politics as a problematic field in search of a solution that cannot, however, be planned from the outset: that is to say, 
normative invention can only be the outcome of a process of experimentation in which finalities are allowed to emerge within political struggles, rather than depending on a specific theory of human nature.

In fact, Simondon's theory transfers the focus on human nature traditionally held in political thought to political processes and relations as such. Simondon's thinking on psychic and collective individuation is at the heart of this gesture: it serves to demystify the very scope of political theory by dethroning the image of human nature, which the politicalphilosophical conception of the body politic has always been based on, including the modern notion of an individualistic nature of human beings that can be artificially organised. Simondon subtracts political theory from all dialectics of individual and society. As will be discussed below, the biological, technical, psychic and collective processes analysed by Simondon under the concept of the 'transindividual' are neither independent of, nor entirely determined by, individual agency. Instead, they comprehend the individual as part of a broader set of systemic relations by which the latter is both mediated and constituted, playing different roles according to the shifting configuration of the system.

From this perspective, the problem for politics is that of the relation between the existing configuration of the social system and the possible emergence - from within it - of a normative invention that would affect all of its apparatuses of homeostatic regulation: beliefs, myths, norms, jurisprudence, institutions. Within such a complex system there can be no expectation of a definitive, 'neutral', solution to political problems, because theory itself is embedded in a complex set of normativities that undermine the very distinction between theory and praxis. As we shall see, this makes of what Simondon calls 'philosophical thought' a specific kind of political techne of normative invention, the function of which cannot be understood without first grasping its peculiar relation to technics and, more generally, to the regulative function of culture within social systems.

\section{Culture as the Regulatory Apparatus of Social Systems}

The function Simondon attributes to culture as a regulatory apparatus of social systems can only be grasped with an adequate understanding of the concept of the transindividual. 
Simondon's basic assumption is that human nature is as much a factor of destabilisation as of structuration within society. He argues that what most puts at risk the normative stability of social systems are the biological and technical patterns that characterise individual and collective behaviour (Individuation, p. 508). In this sense, 'human nature' is not merely a given fact, but the biological-technical basis for processes of psychic and collective (that is 'transindividual') individuation, out of which a symbolic milieu of 'norms which do not exist at the biological level' emerges (Individuation, p. 282).

Human nature can thus be said to always exceed the established normativity of a social system in at least two ways. On the one hand, biological normativity re-appears in the form of instinct at the moment of birth, thereby making each new individual and its drives a sort of biological surplus, namely, a problem of integration that must be solved through education - the symbolic capture into an 'elementary normativity ... affecting the individual' and without which society would be impossible (Individuation, p. 506). On the other hand, technical normativity represents a constant challenge to the self-referential continuity of the symbolic milieu which regulates social reproduction. As a result, technical normativity is driven by an irreducible relation to changes in the natural environment where its products namely, technical objects - must necessarily be embedded in order to function.

In short, both biological and technical normativities - which depend on the long-term historicity of the natural environment - cannot be entirely absorbed within the recurring normativity established by symbolic practices, which, by contrast, depends on the specific historicity of each social system. In this sense, both biological and technical normativities force the social system to repeat the effort of symbolising their products. This is an endless effort, because, although what is organic and technical always threatens the system's stability, it cannot simply be neutralised, as it is the precondition of at once its existence and functioning. Therefore it has to be continuously 'manipulated' in order to maintain group cohesion. What intervenes to stabilise the system at this level is culture, by, as Simondon puts it, 'MANIPULATING in some way the symbols representing such a technical gesture or such a biological drive' (Individuation, p. 504). But the efficacy of such an operation of 'human 
engineering [manipulation humaine]' is always partial, precisely because of what 'human nature' is (or, more accurately, what it is not).

As Simondon suggests, the transindividual relations emerging from this process constantly integrate the normativities exceeding the normal functioning of the social system by 'enveloping them [les enveloppant]' with a layer of 'significations' (Individuation, p. 307). This 'essentially regulative [régulatrice par essence]' layer of significations is culture ( $D u$ mode, p. 16). Thus, in a crucial passage in Du mode, Simondon defines culture as the regulatory apparatus of social systems:

Culture is that through which human beings regulate their relation to the world and to themselves ... [It is] that part of human reality that can be modified ... the active intermediary between successive generations [across time], coeval human groups [across space], and between successive or coexistent individuals [across both time and space]. (Du mode, p. 227, italics added)

Culture is active because, despite depending on a technical-biological 'base', it is not simply its super-structural or mythological expression. It is not, in Simondon's words, the 'means of expression' to which both Marxism and Freudianism reduce it, but rather 'a set of action potentials, equipped with highly complex schemas ready to be actualised' (Individuation, p. 504). And it is an active intermediary, which, by retroacting on the biological and technical normativities on which it in turn relies, serves to modify the functioning and development of the individuals involved and of the social system at the same time.

It is in this sense that culture can be said to be 'reflexive' and regulative. Simondon's peculiar use of the term 'reflexivity' points to the feedback effect that the intermediary apparatus of 'culture' enacts on the social system. This apparatus integrates proto-social normativities (biological and technical) into a 'tradition' sedimented as part of a shared symbolic milieu. Technical activity, however, is suspended, as it were, between nature and culture, and therefore plays a unique role within social dynamics. This role is to be differentiated not in terms of contents, but in terms of the separate functional supply that technics provides to the value-structure of the social system. On the one hand, biological norms introduce into the social system a 'binary' logic, which is typical of a 'closed 
community' and is ultimately founded on organisms' natural opposition between 'good' and 'poisonous'. This tendency towards closure is instituted within human communities as an opposition between sacred and profane, which divides and separates what is internal from what is external to the community. Thus from the perspective established by sacredness 'external communities are conceived - because external - as bad'. The 'bipolarity of values', which underwrites notions of the sacred, thereby finds itself in tension with technical activity, which instead brings forward a 'unipolarity of values' tending towards constructive integration (Individuation, p. 509).

This opposition between sacredness and technicity accounts for the tension between 'closing' and 'opening' processes within the social system. Simondon explicitly frames this, notably in his text Psychosociologie de la technicité, as a tension between the regulative function of 'sacredness' (and, to a certain extent, of the symbolic function in general), and the inventive function of 'technicity' - which is crystallised within technical objects (see Simondon, 2014, pp. 67-69, 116-17, 127) as 'a set of sensory-motor schemas, rationally intertwined and organised, as in an organism' (Van Caneghem, 1989, p. 824). Technicity relies on 'schemas of action', which functionally reflect biological needs shared by the entire species and depend on the matter on which they act. As Simondon makes clear, 'technical norms are entirely accessible to the individual without him needing to rely on a social normativity'. Consequently, technical normativity can circulate between different social systems, bypassing what Simondon refers to as their 'collective mythology' (Individuation, pp. 513-14). Thus, following in the footsteps of the French paleoanthropologist LeroiGourhan (1943-45), Simondon maintains that the adoption of any technique has intrinsic political implications:

When a closed society incorporates a new technique, it also incorporates the values inherent to the social character of that technique, thereby giving rise to a restructuring of its own value system. Since all communities use techniques or are bound to introduce new ones, no community can be either completely closed or not subject to evolutionary change. (Individuation, pp. 513) 
Against this background, the intrinsic political power of philosophy - understood as a reflexive activity that produces symbolic objects - can finally be grasped. According to Simondon, 'philosophical thought' emerges out of processes of psychic and collective invention, which serve to restructure the normative underpinnings of the social system as a whole. Crucially, as a subset of the cultural apparatus, philosophical thought might be said to carry the same regulative function: by retroacting, or 'reflecting', on the cultural milieu of which it is a part, philosophical thought acts on the social system as a higher-order regulatory mechanism that provides stability. In this sense, philosophy works as an element of culture capable of modifying the regulatory apparatus itself in accordance with the discontinuities that emerge from human biology and technical invention. Thus Simondon explicitly conceives of his philosophical enterprise - and of Du mode in particular - as an attempt to integrate technology into culture - the regulatory apparatus of the social system - through the means of philosophical reflection.

However, for Simondon, philosophy cannot be restricted to the merely regulative role of stabilising culture because it enjoys a specific relation with technical activity. Like technical products, the symbolic products of philosophical thought are constantly interacting with the configuration of the cultural milieu out of which they emerge. Within this milieu, these symbolic objects circulate in the form of a discontinuous pattern, which is transformative rather than reproductive precisely because of the original relation between 'philosophical thought' and 'technicity'. Tracing this relation back to its pre-Socratic roots is thus the key to Simondon's own philosophical practice of thinking as a special kind of political technē. But this aspect cannot be uncovered before clarifying how Simondon's attack on Aristotle's notion of technē supports his critique of Heidegger's understanding of the relation between techne and thinking.

\section{Aristotle, Heidegger, and the Subordination of Technē}

Simondon's conception of an original connection between philosophical thought and technicity is an implicit response to Canguilhem's elliptical claim that at stake in his philosophy is 'a new kind of Aristotelianism' based on contemporary telecommunication 
technologies (Canguilhem, 1998, pp. 277-78). In fact, Simondon explicitly based his philosophy of individuation on a direct critique of Aristotle's hylomorphism, which he considered a basic misunderstanding of technics that grounds and affects his whole philosophical system.

As the following will show, Simondon saw the anthropomorphism of Aristotle's 'hylomorphic schema' as responsible for the opposition of the activity of an agent (form) to the passivity of a subject (matter) displayed in his ontology. Moreover, Simondon's critique of hylomorphism can be extended to Aristotle's epistemological distinction, outlined in the Nicomacheian Ethics, between the different forms of knowledge, namely the 'habits (hexeis)' through which the soul possesses truth: technēe (technical knowledge), phronēsis (practical wisdom), and epistēmē (science) (see Nicomachean Ethics, VI.3-8, 1139b15-1142a30, where sophia and nous are also included). Implicit in Aristotle's hierarchical distinction of different forms of knowledge had been a devaluation of poiesis (production) to a subordinate or inferior form of human activity compared to praxis (action) and theorein (contemplation). In my view, this underlying assumption of an ontological hierarchy of human activities also informs Heidegger's own devaluation of techne. . From this perspective, I am going to explain how Simondon's appeal to Ionian philosophers targets both Aristotle's subordination of poiesis to praxis and theorein, and Heidegger's critique of the Greek 'reduction' of thinking to technology.

Simondon opens Individuation with a critique of Aristotle's 'hylomorphic schema' and its latent but undisputed dominion over both common sense and philosophical and scientific thought (Individuation, pp. 48 ff). Although he does not explicitly take on the task of criticising Aristotle's conception of techne, what Simondon says on technicity can be read as going against the rooting of both concepts in a dualistic distinction between form and matter. In Aristotle's hylomorphism, the separation between form and matter corresponds to the separation of a natural goal from its achievement, which is not necessary but only possible (necessity is limited to the unchanging subjects of the theoretical sciences). This distinction - which in Aristotle is even more fundamental than that between nature and 
artifice - constitutes the fundamental tension at the heart of techne, as a form of knowledge related to poiesis, namely, the human activity of supplying matter with form.

For Aristotle, technai are 'productive sciences [epistemai]' (Metaphysics, IX.2, 1046b3; see also Nicomachean Ethics, VI.4) defining areas of limited but systematic craftknowledge. Within these areas, technai are said to actualise their ends, setting the adequate means for their realisation while eschewing deviations. Aristotle's 'official' notion of techne which is determined as the form of knowledge corresponding to poiesis, refers to the knower concerned with production (poiesis) as opposed to the practitioner aiming to utilise the product (poieton) (e.g. Nicomachean Ethics, 1.7, 1098a29-33; see Dunne, 2009, pp. 249-261).

This reference to the product is what ultimately grounds the ontological hierarchy that drives Aristotle's differentiation of phronēsis from technē in book VI: 'phronēsis cannot be ... techne $\ldots$ because acting [praxeos] and producing [poieseos] differ in kind'. 'Action' (praxis), where human matter is involved in the activity of the actor and the action, 'is itself the end', and 'production' (poiesis), where non-human matter is passive and action upon it has 'external' ends, constitute different kinds of human action corresponding to separate forms of knowledge (Nicomachean Ethics, VI.5, 1140b1-7). Even though praxis cannot itself be supreme happiness (eudaimonia) (Nicomachean Ethics, VI.7, 1141a20-22; see also X.6-7), phronessis appears to be a kind of knowledge hierarchically superior to techne, precisely because it works to identify the means to achieve the final aim and supreme good for human beings: theoretical wisdom (sophia), which corresponds to the practice of the highest theoretical activity, namely, the scientific contemplation of unvarying truths (theorein).

Nevertheless, it is still in relation to the undisputed superiority of theorein that the hierarchy between phronessis and technē appears problematic. While the highest form of scientific knowledge concerns what is necessary, phronēsis and technē both concern what 'may or may not be' - namely, the possible - because 'action' and 'production' (praxis and poiesis) both mediate between the potentiality contained in matter and its actualisation according to the ends dictated by the form. More precisely, phronessis rationally sets the means required to reach the ends inscribed in human nature, just as technai set the means appropriate to their products' expected functioning. Within this Aristotelian schema, the field 
of politics is thus marked by the same tension characterising technical production: the definition of its necessary goal is entirely a priori and belongs to science, while the knowledge of the means to achieve it is a matter of skilled virtue.

In this sense, hylomorphism can be said to shape Aristotle's politics by importing into its foundations a tension that is already implicit in his notion of techne - conceived as a minor form of science dealing with both the potentiality of matter in its means and the actuality of form in its goals. In the field of politics, which is exclusively concerned with human praxis, this tension results in a radical separation between an epistēme $\bar{e}$ of universal and necessary ends (practical philosophy) and a specific technique-virtue capable of setting the particular and accidental means of its realisation (phronessis). ${ }^{3}$ Such a separation between a theoretical science of ends and a practical wisdom of deliberation on the right means is emblematically represented in Aristotle's political thought by the figures of Socrates and Pericles, the virtuous philosopher who knows the supreme good rooted in human nature, and the politician concerned with providing the best means to reach it (Nicomachean Ethics, VI.5, 1140b8-10).

Heidegger certainly relies on Aristotle's account of human life as praxis rather than poiesis (Politics, I.4, 1254a7), when he claims that 'existing is action, praxis' (Heidegger, 1998b, p. 48). But what he really aims to challenge is the primacy of theorein. In Being and Time, Vorhandenheit (theorein) is secondary and derivative of Zuhandenheit (poiesis), while both are grounded on the praxis of Dasein (Volpi, 1994; see also Volpi, 2010, on Heidegger's developing relationship with Aristotle). In this way, Heidegger can affirm the primacy of phronēsis. This move reverses but, crucially, does not completely overcome Aristotle's hierarchical classification of the forms of human existence and their corresponding forms of knowledge. Instead, it serves to exacerbate the internal tension characterising the Aristotelian understanding of techne.

Heidegger's technē itself is split between an instrumental, productive, and inauthentic mode of 'being in the world' on the one hand, and a 'mode of knowledge' originally connected with the unconcealment of truth as aletheia on the other - a mode which is revealed in the original Greek meaning of techne as the 'bringing-forth' out of concealment 
which 'never designates the activity of making' (Heidegger, 1998a, p. 35). This results in Heidegger's attack on Greek metaphysics, which he accuses of 'technicising' thinking through the reduction of aletheia to the objective presence of beings required by technology. On this basis, in The Question Concerning Technology Heidegger criticises modern science and technology as embodying the Greek reduction of poiesis to 'making', along with the oblivion of its original dimension as a 'bringing-forth of the true into the beautiful', that is poiesis as what is 'poetical' (Heidegger, 1993, p. 339).

Thus 'reduced' to technology, techne entails an ontological separation of the active agent that forms from the passive matter receiving this form. This, in turn, implies a depreciation of techne , so long as it is conceived as a kind of knowledge irredeemably compromised by the passivity of matter characterising production, and therefore unfit to deal with the sphere of human action, namely politics. As a consequence, a 'political use' of techne $\bar{e}$ is perceived as potentially dangerous, because it does not respect the original praxis characterising human agency. Moreover, it is in this respect that Heidegger develops a normative component: we should take care [Sorge] of thinking against its reduction to a 'technical use'. The diagnosis dictates the cure: 'we must free ourselves from the technical interpretation of thinking. The beginnings of that interpretation reach back to Plato and Aristotle. They take thinking itself to be a techne, a process of deliberation in service to doing and making' (Heidegger, 1998b, p. 240).

This vision of techne is usually shared by all philosophies that, implicitly or explicitly, oppose human activity to the alleged passivity of matter - thereby providing human beings with a designated 'political' status within the rest of nature. It is not by chance that, in this sense, the separation between natural and political theory is common to both Arendt's 'Aristotelian' definition of vita activa and Leo Strauss's 'Platonic' attempt to redefine the status of political theory. The two authors seem to have inherited from Heidegger a similar understanding of phronēsis as a specifically political form of knowledge, through the characterisation of epistemme and technē as forms of knowledge equally inadequate to the understanding of human nature, partially overlooking Aristotle's distinction between ‘practical philosophy' and 'practical wisdom' (phronēsis) (see Berti, 2004). This idea of a 
specifically human praxis serves to preserve the independence of human political action from the supremacy of theory, and, at the same time, defend the field of politics from the risk of being submitted to technocracy.

Following an entirely different path, Simondon takes thinking itself to be a techne, and goes on to develop at the same time an idea of the technicity of philosophical thought as something to be taken care of (see Stiegler, 2009; Barthélémy, 2015). This coincides with a critique of any hypostatisation of a specific human praxis that may define the field of politics (see Guchet 2010, pp. 131-32, 170-72; Bardin 2015, pp. 229-34), going against Heidegger's warning not to 'take thinking itself to be a techne', and even beyond Arendt's own attempt to attribute human content to the 'world of things'. In fact, Arendt's valuation of homo faber still presupposes a hierarchy of human action, at whose extreme lies a wordless animal laborans - a hierarchy, therefore, that is ultimately grounded on the opposition between human and animal life (Arendt, 1958; see Loeve 2011, pp. 37-38, 44-47). By contrast, Simondon's philosophy instead challenges the very ontological distinction between inert matter and human beings, thereby liberating technics from the Aristotelian 'hylomorphic schema'. Thus, Simondon's move also collapses the hierarchy between the domains of epistēmē, phronēsis and techne, and any hierarchy between the different fields of human activity and knowledge. It was from this hierarchy that Western political theory emerged as a peculiar science dealing with the political nature of humans defined in opposition to their divine capacity to contemplate truth, on the one hand, and their animal necessity to work for survival, on the other.

Against this background, Simondon appeals to Ionian philosophy as the common source of philosophical thought and technicity. In an implicit challenge to Heidegger's sequence of 'inceptional' thinkers (Anaximander, Heraclitus and Parmenides) (Heidegger, 1992, pp. 7-8), Simondon argues that the technicity originally inhabiting the Ionian philosophy of physis was betrayed by Eleatic philosophy, which preluded Attic dualism, namely, 'a type of thinking ... resulting from a veritable break within experience, and dividing world and knowledge in order to oppose itself to the genetic and experimental positivism of physis' (Individuation, p. 341). As he sought an alternative to Heidegger's 
interpretation of pre-Socratic thought as the 'disclosure of the Being of beings as a problem' (Heidegger, 2008, p. 46), Simondon portrayed the dawn of Western philosophy as an original betrayal of the technical and experimental nature of 'philosophical thought' (Individuation, p. 339). Thus he challenged the very opposition between thinking and techne - a position which, as the following pages will show, is exemplified in his notion of 'philosophical thought' as a political-pedagogical technē.

\section{Philosophical Thought as Political Technē}

Simondon opens his History of the Notion of the Individual by referring to pre-Socratic thought as a source of 'reflexive processing [élaboration réflexive]' (Individuation, p. 339). According to Duhem (2012), Simondon's interpretation of pre-Socratic thought relies on the 'reflexive potential' offered by their philosophy of physis. In my view, this claim should be rather understood in light of a passage in his Complementary Note, where he states that 'Thales, Anaximander, Anaximenes [were] first of all technicians', namely, that each of them represented a 'pure individual who brings together within himself the two conditions of reflexive thought [pensée reflexive], organic life and technical life' (Individuation, pp. 51112). The 'technician' is partially detached from his community because he is embedded in the biologically based universality that characterises the technical relationship to nature (Simondon 2010, p. 233). This position is what makes of the philosophers of physis the models of 'pure individuals', capable of a 'direct dialogue with the world', that is able to invent and mediate the potentially universal relation between social systems and 'non social' objects (Individuation, pp. 512).

In the closing sentence of Individuation Simondon explicitly identifies such an individual as 'the amplifier issued from Nature' through which 'societies become a World' (Individuation, p. 335). This means that, for Simondon, the mediation between social groups and their common natural milieu is an inherently technical relation, one that is marked by the mediating function of individuals in which a 'technical mentality' is embedded. In his conclusion to the Complementary Note he goes even further, recognising such a function in the technical object itself, as it 'goes beyond the communitarian reality in order to institute a 
relation with Nature', thanks to the technical normativity with which it is endowed (Individuation, p. 527, see also p. 523, and Simondon, 2005b, p. 85). What is of real concern here is not the nature of the actor, but the very potentials for normative invention conveyed. These technical 'mediators' circulate, and retroact onto the cultures they emerge from through a 'feedback' - or, Simondon puts it, 'reflexive' - effect, inducing the emergence of normative invention and the political transformation of the social system concerned.

Among these mediators, the symbolic products of philosophy play a very special role. When referring to the 'great path' opened by the Greeks, Simondon defines philosophy as the teaching of 'inspiring' and 'fertile' 'a priori images' that, once 'integrated in the world as long term anticipations', act as the seeds of political innovation (Simondon, 2008, p. 61). The symbolic objects produced by philosophy should thus be considered as mediators of political action because they are the products of processes of collective invention that - through pedagogical practice - can retroact on the very processes of individual and collective individuation they emerge from, thereby catalysing normative invention. Thus understood, philosophy possesses an irreducible political dimension because a mixed symbolically and technically mediated relation defines the human political 'condition', where communitarian constraints are constantly crossed by the universalising tendency of technics. In this 'metastable' field, the internal tensions characterising the symbolic products of philosophy show their connection to both technicity and sacredness, thus making philosophy at once 'constructive and regulative of culture' (Du mode, p. 212, italics added).

From this standpoint, Simondon's conception of Ionian philosophy as a source of 'reflexive processing' can be seen as aimed at conceiving philosophy itself as a special kind of pedagogical techne. And, in effect, Simondon's enterprise as a whole presupposes that the productions of philosophical thinking cannot be confined to the domain of contemplation, and are in fact entangled in a pedagogical practice specifically concerned with technics. Since his earliest pedagogical activity as a lycée philosophy professor in 1953-54, Simondon sought to plan the development of a 'technical mentality' (Simondon, 2014, pp. 203, 224, 233; see Carrozzini, 2011). Informed by knowledge of the actual functioning of technical objects, as well as a rejection of all abstract representations of their functioning (whether through 
biological analogies or the still too simplistic image of machines provided by classical mechanics), technical mentality would open theory to new 'schemas' for envisaging political regulation (Simondon, 2012, pp. 3-4). The political implications of such a pedagogy of technicity lie in the fact that learning from technical schemas, driven as they are by an open and experimental relation to the natural environment, entails the possibility of an escape from the normative constraints of a given community, and of the emergence of new values. On the contrary, trying to 'limit the technical gesture according to cultural norms would imply the definition of 'a kingdom of ends, a final code of values' de facto mirroring and reproducing the status quo (Simondon, 2015, p. 21).

Hence the political efficacy of philosophical thought is to be conceived as a paradoxical conservation of the openness of culture to normative invention - a 'tradition of invention', as I have tried to argue. Such a paradoxical definition can eventually explain the common purpose of Simondon's two major philosophical works. Despite their apparently unrelated concerns, i.e. individuation and technics, they are 'symbolic products' that look to a single Simondonian project of the institution of a political pedagogy of technicity.

On the one hand, a study of Individuation can be a 'source of paradigms' precisely because it grasps the actual processes from which it derives its schemas, while the hylomorphic schema, on the contrary, by abstractly opposing inert matter to the living, isolates philosophy and any form of theory from the mixed biological, technical and political milieu it emerges from:

The opposition between the inert and the living is derived from the hylomorphic schema ... The study of individuation ... is a source of paradigms; yet it cannot logically be a source of paradigms unless it can also be, at least hypothetically, a grasping of the concrete becoming [devenir réel] out of which the domains of application of the schemas it generates constitute themselves. (Individuation, pp. 32324)

On the other hand, the philosophy of technics displayed in Du mode is intended to provide a joint epistemological and political impact: 
The analysis of the mode of existence of technical objects therefore has an epistemological significance ... [T] he technical operation is a pure operation involving the true laws of natural reality ... Philosophical thought - insofar as it has issued from tradition and employs schemas that have issued from tradition - does not entail any reference to this intermediate reality [i.e. technicity] between labour and scholé ... [However] the [hylomorphic] dualism inherent to philosophical thought ... will be profoundly modified by the introduction of technical activity as a subject of philosophical reflection ... It seems that this opposition between action and contemplation, between the immutable and the moving, must cease when the technical operation is introduced as an element [terme] of reflection and even as a paradigm.

(Du mode, pp. 255-56)

According to Simondon, philosophical thought, besides being a part of culture ("issued from tradition'), also depends on a tradition of technical invention. Originally triggered by preSocratic 'technicians', the historical connection between philosophy and technics rests on a deeper link between the practice of philosophy and technical normativity conceived as a vector of social change. From Simondon's perspective, philosophy is a tradition that emerges from the invention and propagation of certain technical objects, archetypal techniques, or paradigms. Such a tradition is not composed of universal elements, but rather of 'patterns' of thinking and action ('schemas' in Simondon's words) that come to be crystallised in the form of symbolic artefacts and which are subsequently reactivated in specific circumstances. Since its Ionian origin, it is primarily within technical objects and the 'technical operations' they entail that 'philosophical thought' can both find a ground for reflection and establish a paradigm, although the reactivation of this reservoir of ideas and schemas of thought has for too long been hindered by the integration of philosophy into the regulatory function of culture. According to Simondon, it is the intrinsically technical nature of philosophy which following its politico-pedagogical vocation - should be revived in order to aim "not only at the discovery, but also at the production of genetic essences' (Du mode, p. 213), that is, symbolic objects that convey the schemas of technical operations that are in turn re-invented within the historicity of a specific cultural milieu. 
In light of its original and intrinsic connection to technics on the one hand and symbolic practice on the other, philosophy cannot be understood as the property of an invariant human nature. It should rather be grasped as a tradition capable of assuming the destabilising force of collective processes of invention, and elaborating their integration within the regulatory apparatus of social systems, that is culture. Thus the symbolic products of philosophy serve as triggers for inherently political processes that de-structure and restructure social systems. But philosophy can be the source of social change precisely because of its 'metastability', a tendency to 'amplify' the schemas implicit in other processes whether technical, scientific, ethical, aesthetic or linguistic - that does not follow an entirely pre-established normativity. As a consequence, the functioning and efficacy of philosophy cannot be secured once and for all. It can only continue under the condition of the renewed collective invention and integration of its products within different social systems and across different historical epochs, and, for this very reason, what Simondon calls 'philosophical thought' is open to the permanent risk of extinction. Simondon conceived his own research as part of this struggle for the continuation of philosophical thought, and the unity of his $2 u v r e$ can only be perceived from such a perspective, which also involves a plea for the intrinsic political significance of the philosophy of technics.

\section{References}

Angier, T. (2010), Techne in Aristotle's Ethics: Crafting the Moral Life. London: Continuum. Arendt, H. (1958) The Human Condition. Chicago, IL: University of Chicago Press.

Aristotle (1991) The Complete Works of Aristotle, Translated by J. Barnes. Princeton, NJ: Princeton University Press.

Balibar, É. (1997) Spinoza: from Individuality to Transindividuality. Mededelingen vanwege Het Spinozahuis 71: 3-46.

Bardin, A. (2015) Epistemology and Political Philosophy in Gilbert Simondon: Individuation, Technics, Social Systems. Dordrecht: Springer.

Barthélémy, J.H. (2008) Simondon ou l'encyclopédisme génétique. Paris: PUF. 
Barthélémy, J.H. (2015) Life and Technology: An Inquiry into and Beyond Simondon. Luneburg: Meson Press.

Bergson, H. (1932) Les deux sources de la moralité et de la religion. Paris: Alcan.

Berti, E. (2004) The Reception of Aristotle's Intellectual Virtues in Gadamer and the Hermeneutic Philosophy. In: R. Pozzo (ed.) The Impact of Aristotelianism on Modern Philosophy. Washington DC: The Catholic University of America Press, pp. 285-300.

Canguilhem, G. (1998) The Normal and the Pathological. New York: Zone Books.

Canguilhem, G. (2002) Le problème des régulations dans l'organisme et dans la société. In: Écrits sur la médecine. Paris: Seuil, pp. 101-125.

Carrozzini, G. (2011) Gilbert Simondon filosofo della Mentalité technique. Milano: Mimesis. Combes, M. (2013) Gilbert Simondon and the Philosophy of the Transindividual. Cambridge, MA: MIT Press.

De Boever et al. (2012) Being and Technology. Edinburgh: Edinburgh University Press.

Deleuze, G. (1966) Gilbert Simondon, L'individu et sa genèse physico-biologique. In: L'île déserte et autres textes. Paris: Minuit, pp. 120-124.

Del Lucchese, F. (2009) Monstrous individuations: Deleuze, Simondon, and relational ontology. Differences 20(2-3): 179-193.

Duhem, L. (2012) Apeiron et physis: Simondon transducteur des Présocratiques. Cahiers Simondon 4: 33-67.

Dunne, J. (2009) Back to the Rough Ground. Practical Judgment and the Lure of Technique. Indiana: University of Notre Dame Press.

Feenberg, A. (1991) Critical Theory of Technology. Oxford: Oxford University Press.

Guchet, X. (2010) Pour un humanisme technologique. Culture, technique et société dans la philosophie de Gilbert Simondon. Paris: PUF.

Guchet, X. (2011) Technology, sociology, humanism: Simondon and the problem of the human sciences. SubStance 129(41/3): 76-92

Harvey, A.D. (2007) Body Politic: Political Metaphor and Political Violence. Newcastle: Cambridge Scholars Publishing.

Heidegger, M. (1992) Parmenides. Bloomington: Indiana University Press. 
Heidegger, M. (1993) Basic Writings. New York: HarperCollins Publishers.

Heidegger, M. (1998a) Off the Beaten Track. Cambridge: Cambridge University Press.

Heidegger, M. (1998b) Pathmarks. Cambridge: Cambridge University Press.

Heidegger, M. (2008) Basic Concepts of Ancient Philosophy. Bloomington: Indiana University Press.

Kantorowicz, E. (1957) The King's Two Bodies: a Study in Mediaeval Political Theology. Princeton, NJ: Princeton University Press.

Leroi-Gourhan, A. (1943-45) Evolution et techniques, 2 vols. Paris: Albin Michel.

Loeve, S. (2011) Technique, travail et anthropologie chez Arendt et Simondon. Cahiers Simondon 3: 31-49.

Marcuse, H. (1964) One-dimensional Man. London: Routledge \& Keagan.

Mayr, O. (1986) Authority, Liberty and Automatic Machinery in Early Modern Europe.

Baltimore-London: Johns Hopkins University Press.

Schlanger, J. (1995) Les métaphores de l'organisme. Paris: L’Harmattan.

Simondon, G. (1989[1958]) Du mode d'existence des objets techniques. Paris: Aubier.

Simondon, G. (2005a[1958]) L'individuation à la lumière des notions de forme et information. Grenoble: Gerome Million.

Simondon, G. (2005b) L'Invention dans les techniques. Paris: Seuil.

Simondon, G. (2008) Imagination et invention. Chatou: La Transparence.

Simondon, G. (2010) The Limits of Human Progress: A Critical Study. Cultural Politics 6(2): 229-236.

Simondon, G. (2012) Technical Mentality. In: De Boever et al. (eds.) Being and Technology. Edinburgh: Edinburgh University Press, pp. 1-18.

Simondon, G. (2014) Sur la technique. Paris: PUF.

Simondon, G. (2015) Culture and Technics. Radical Philosophy 189: 17-23.

Simondon. G. (1964) Gilbert Simondon, L’individu et sa genèse physico-biologique. Paris: PUF.

Stiegler, B. (1998), Technics and Time 1. Stanford: Stanford University Press. 
Stiegler, B. (2009) The Theatre of Individuation: Phase-Shift and Resolution in Simondon and Heidegger. Pharresia 7: 46-57.

Toscano, A. (2006) The theatre of production: philosophy and individuation between Kant and Deleuze. Basingstoke: Palgrave Macmillan.

Van Caneghem, D. (1989) Hommage à Gilbert Simondon. Bulletin de Psychologie 42(392): $815-836$.

Volpi, F. (1994) Being and Time: A “Translation” of the Nichomachean Ethics? In: T. Kisiel and J. Van Buren (eds.) Reading Heidegger From the Start. Albany: State University of New York Press, pp. 195-211.

Volpi, F. (2010) Heidegger e Aristotele. Bari: Laterza.

Wiener, N. (1954) The Human use of Human Beings: Cybernetics and Society. London: Eyre \& Spottiswoode.

While Du mode was immediately published in 1958, only the first part of Individuation (Simondon, 1964) appeared in print during Simondon's lifetime. I will hereafter use the following abbreviations: Simondon, 2005a[1958] = Individuation; Simondon, 1989[1958] = Du mode. I have provided my own translations of Simondon's works, or modified the translations I refer to, according to my interpretation.

'Simondon's project for a 'general theory of the human sciences' was an original reworking of the French sociological tradition that relied on a critical revision of the concepts of form and information elaborated within the Gestalttheorie and cybernetics (Guchet, 2011; see in particular Individuation, pp. 531-55). Because the focus of this article is Simondon's work, I shall avoid references to twentieth-century social system theories, such as those of Talcott Parsons and Luhmann, which Simondon does not deal with in his writings.

${ }^{3}$ The distinction between phronēsis, technē and epistēmē in Nicomachean Ethics, VI, is not to be confused with the distinction between 'practical, productive or theoretical' sciences in Metaphysics, VI.2, precisely because sciences (epistemmai) do not deal with 'the accidental' as phronēsis and technē have to. 